\title{
Succession Planning in Malaysian Institution of Higher Education
}

\author{
Zaini Abdullah \\ UiTM International Centre \\ Universiti Teknologi MARA, 40450 Shah Alam, Selangor, MALAYSIA \\ Tel: 60-3-5544-4936 E-mail: zabadu@salam.uitm.edu.my \\ Siti Akmar Abu Samah \\ UiTM International Centre \\ Universiti Teknologi MARA 40450 Shah Alam, Selangor, MALAYSIA \\ Tel: 60-3-5544-4935Ｅ-mail: sitiakma@salam.uitm.edu.my
}

Kamaruzaman Jusoff (Corresponding author)

Yale University

Yale Tropical Resources Institute, 370 Prospect St, New Haven, CT 06511-2104, USA.

Tel: 203-676-7761Ｅ-mail: jusoff.kamaruzaman@yale.edu

Posiah Mohd Isa

i-LEC, Universiti Teknologi MARA 40450 Shah Alam, Selangor, MALAYSIA

Tel: 60-3-5544-2608Ｅ-mail: posiah@salam.uitm.edu.my

The research is funded by Higher Education Leadership Academy (AKEPT), Ministry of Higher Education (MOHE), Malaysia (Sponsoring information)

\begin{abstract}
Succession planning has not been a distinct initiative undertaken by educational organisation in their strategic planning. The former has been clearly established in several high profile profit organisations to ensure smooth transition of leadership in their respective department. From several literatures, proponents of strategic planning have called for non-profit organisations to seriously consider succession planning as an indispensable initiative. This is because it promotes a clear vision of shared values, personnel efficiency and effectiveness and institutional credibility. Therefore, it has to be undertaken by the educational organisation as it promotes positive outlook within. Subsequently, it acts to provide motivational booster for the workers as in talent pooling, customers' satisfaction due to institutional effectiveness and the organisation competent management at large. This paper explores the importance of succession planning on the sustainability of the educational organisation. It also attempts to put into perspective how succession planning transcends these effects on the performance of academicians, students and the organisation stability.
\end{abstract}

Keywords: Succession planning, Strategic Talent pool, Sustainability, Educational organisation

\section{Introduction}

Succession planning is a means of identifying critical management positions. It may start at the levels of project manager, supervisor and extending up to the highest position in the organisation (Rothwell, 2005). It also describes management position to provide maximum flexibility in lateral management moves and to ensure that as individuals achieve greater seniority, their management skills will broaden and become more generalised in relation to total organisational objectives rather than to purely departmental objectives. In this paper the discussion centres on the 
succession planning in a non-profit organisation which focuses on public educational organisation in which personnel development should create effectiveness and efficiency and enhance institutional credibility.

\section{Succession planning in an educational organisation}

Although succession planning has spelt many affirmative returns to organisations, several reviews have indicated that this corporate initiative lacks in its planning, implementing and managing. Due to these setbacks, this initiative, all too often revered by many successful organisations, may not be too popular by educational organisation. However, several literature have indicated hopes that this initiative can be a significant step in planning for effective pool of talented academicians for the purpose of managerial duties execution in the educational sector. Clunies (2007) reiterates that although it is difficult to implement in academia, he is hopeful that this initiative can begin with plans that are simple and tailored to the need of the educational organisation. His article quoted works of Eastman (1995) which display three elements of concern; the purpose of the initiative, who will this initiative serve and the desired outcomes. It may be a common initiative practised in high profit organisations such as Nokia and GE (Groves, 2007)..

Other works have indicated that succession planning can be carried out in higher education for effective human resource development. Although Rothwell (2005) focuses on profit organisation, he underlines the importance of succession planning as an effort for individual development that should include any job category. He seems to believe that in any case of staff shortage, it would bring disaster or chaos to the performance of the organisation for that particular time. Hence, he urges the need to extend succession planning not only at management ranks, but also throughout the empowered workforce. As this paper concerns the non-profit organisation, it is pertinent to note that succession planning is as important in both types of organisation. This is evident in Chambers et al (1998) as they maintain that succession planning is an important way to sustain the staff availability. With the increase of competition nowadays, both profit and non-profit organisations are competing to attract and retain talents.

Non-profit organisations are on the verge of what most experts use the term brain drain syndrome, as many talents go to profit organisation because they provide feasible career path and attractive salary and other attractive and lucrative benefits. This challenge has been the effect of the difficulties in constructing a comprehensive succession planning caused by the shortage in talents inside the organisation and high level of turnover phenomenon. Being one of the several factors observed, is the issue of globalization in which there is an increase in uncertainty in the econoy that affects the profit organisation, though not so much of non-profit organisation, but the situation may subsequently arises in the latter. In such scenario, employees have become anxious about their job security that they start to think and search the organisation that can provide positive assertions. The increasing trend of turnover sometimes is worsened by the lack of adequate programme to groom the existing talent.

Clunies (2007) believes that higher education has historically been slow to adopt many corporate management processes. He therefore has a reasonable doubt for the readiness of the institution to employ succession planning or any executive development programme because of dramatic cultural differences between the boardroom and the campus. Rosse \& Levine (2003) support this argument by stating the complex and bureaucratic procedures for hiring compared with many profit organisations or business corporations. Nonetheless, this does not mean that institution of higher education lack strong corporate values. Carey et al (2000) reiterate that there are parallel values between higher education with business corporation. On the contrary of what most experts believe, institution of higher education has several values that depict its potential to succession planning. These comparative values between the business corporation and institution of higher education are shown in the Table 1 below.

$<<$ Table 1. Comparative values of core principles in succession planning between business corporation and institution of higher education $>>$

\section{The significant impact of succession planning in institution of higher education}

In support for the earlier argument, succession planning although seldom heard of in non-profit organisation, can be promoted in institution of higher education through the core values of the principles displayed in the table above. The table indicates that there is hope for such corporate based initiative being driven in institution of higher education. Wolfred (2008) states that even in the most developed countries, succession planning which is part of the strategic leader development programme is seldom heard of especially at university level. This may be caused, as he states, by the bloated bureaucracy or lack of such management training in the institution. Although succession planning is usually associated with large corporation, it is also important that it becomes an initiative in every organisation. That being said, a good succession planning can reduce the risk of educational disorganisation, as far as appointing the rightful candidate to hold academic manager positions is concerned. This usually happens at the end of tenure, on long absence or appointment vacancy. Hence, succession planning helps to ensure the sustainability of an organisation (Rothwell, 2005).

The subsequent discussion focuses on the expectations required of academic managers and hence display the impact of succession planning if it is adopted in institution of higher education. Effective managerial skills of academic managers 
are essential as they create strong relationships between and within organisations involving the providers and customers (Deem, 2007; and Newman 2000) skills comprising theories, techniques and behavioural guidelines, if are effectively applied, will enhance the manager's practice. In the education set up, academic managers are those responsible to the dean of faculty for matters pertaining to the management, organising and delivering of duties for teaching, and the administration of research in the faculty. However, apart from having the teaching role himself, academic manager specific job specification will be agreed upon with the dean of faculty from time to time and the duties may commensurate with the changing needs of the faculty.

Within the faculty, academic managers are required to manage the process of curriculum review which involves looking through the courses offered by the faculty. These include the mentoring duties on to the curriculum which involves course content, methods of delivery and assessment and most importantly the documentation of these matters, either manually or electronically, the duty also negotiation of these developments through the faculty and the university processes. This will include the development of links with other faculties in the University and, perhaps, with other universities with a view to the provision of collaborative courses.

Academic manager at his faculty level has to manage the process leading up to the faculty regularised teaching quality assessments. This includes preparing self-assessment programme, making recommendations for improvement, preparing and compiling of documentation, liaising with staff of the faculty academic office, ensuring detailed arrangements for assessment visits are made, meeting with assessors and also preparing for the process of accreditation of the faculty courses by the relevant professional bodies. These job specifications are essential requirements of academic manager which warrants for managerial skills. Delivering the knowledge on managerial skills will require the teaching from leaders in a systematic best practice and this is commonly developed through mentoring relationships. Research on mentoring has evidenced that employees with mentors are much more likely to experience a range of positive outcomes (Groves, 2007; Lankua \& Scandura, 2002).

For more precise duties, in the faculty, academic manager needs to assist with management procedures related to research activities. The duties will depend on other loads, but might at times include help with production of documents for the Research Assessment exercises and the faculty annual research report. Among others also include drafting publicity about the faculty and its courses for inclusion in the University's undergraduate and postgraduate prospectuses and other similar publications, including electronic information sources. The managerial skills of academic managers have to be complemented by knowledge on attending and reporting to faculty committee meetings, and participating in several additional faculty committees related to management of teaching and research or external liaison.

Academic managers in the university have duties that involve them in the membership of various committees within the faculty as well as the university. They keep a very close liaison with other officers within and outside the faculty, in the faculty and the university, and at the same time assist in the promotion of the activities conducted by the faculty elsewhere in the University and to external agencies (Coxhead, 2007). Hence, the better way is to train academic managers in a systematic pooling of potentials and prospects with development programme to ensure smooth transition of leadership and execution of duties.

Although it is commonly practised in corporate organisation, good succession planning will systematically help prospective academic managers to streamline their managerial skills to ensure effectiveness and smooth running of the institutions, for new leadership roles as the need arises or when one's term has ended (Boettcher \& Craven, 2008). There is a need for selection criteria for these talents to be readily 'groomed' for managerial position in the academic institution. The establishment of the succession plan and related models help to nurture and strengthen the high performance culture in institutions of higher education via professional work force that exhibits self personality and professional personality, possession of competency and vital values towards sustainable achievement of their future. The key strategy of the succession plan is to mould and harness the talent of professional work force at academic managerial level to fill in strategic positions. It also aids in the career path and laid foundation of guidance necessary for the accomplishment of tasks and duties of the future.

\section{Conclusion}

Several literature have stated that whether these initiatives are termed as succession planning and management, building bench strength, or talent management, it is clearly indicated that, that such a deliberate and systematic identification, engagement and retention of potential leaders and talented performers, and the achievement of targeted results display compelling evidence that this focused attention produces positive performance of the academics in educational organisation. However, the proponents of succession planning have also cautioned that succession plans, whether it is in a corporate or higher education should not function as an isolated system but rather as an integral component of the overall human resources planning process.

\section{References}

Boettcher, S. and Craven, A. (2008). Succession Planning for Higher education CIOS What Why How, UT Health Scince Center San Antonio. 
Carey, D. C., Ogden, D., \& Roland, J. A. (2000). CEO Succession. Oxford University Press: New York.

Chambers, E.G., Foulton, M., Handfield-Jones, H. Hankin, S.M., \& Michaels, E.G. (1998). The War of Talent. In J. M. Hiltrop (Ed.). (1999). The Quest for the Best: Human Resoruces Practices to Attract and Retain Talent. European Management Journal . 17(4): 422-430.

Clunies, J.P. (2007). Benchmarking Succession Planning and Executive Development in Higher Education: Is the Academy Ready Now to Employ these Corporate Paradigms? Academic Leadership The Online Journal Vol.2 Issue 4 February 13, 2007.

Coxhead, P. (2007). University of Birmingham Academic Manager Job Description Computer Science taken from http://www.cs.bham.ac.uk/ pxc/pers/jobspec.html 9 August 2002 rretrieved on 4 July 2008.

Deem, R. (2007). "Managing Contemporary UK Universities - Manager-Academics and New Managerialism" Academic Leadership - The Online Journal Vol. 1 No.3.

Eastman, L.J. (1995). Succession Planning: An Annotated Bibliography and Summary of Commonly Reported Organisational Practices, North Carolina: centre for Creative Leadership, Greensboro, NC.

Groves, Kevin S. (2007). Intergrating leadership development and succession planning best practices, Journal of Management Development Vol.26, No.3, pp 239-260 Emerald Group Publishing Ltd.

Lankua, M.J. \& Scandura, T.A. (2002) "An investigation of personal learning in mentoring relationships: contents, antecedents and consequences " Academy of Management Journal. 45(4): 779-90.

Newman, K.L. (2000). "Organisational Transformation During Institutional Upheaval" Academy of Management Review. 25 (3): 602-619.

Rosse, J. G. \& Levin, R. A. (2003). Academic Administrator's Guide to Hiring-Between the Lines. Jossey-Bass: San Francisco.

Rothwell, W. J. (2005). Effective Succession Planning: Ensuring Continuity and Building Talent from Within $3^{\text {rd }}$ Edition. American Management Association (AMACOM).

Wolfred, T. (2008). Building Leaderful Organisations: Succession Planning for Nonprofits. The Anne E. Casey Foundation: Baltimore, Maryland.

Table 1. Comparative values of core principles in succession planning between business corporation and institution of higher education

\begin{tabular}{|l|l|l|}
\hline No. & Business Corporation & Institution of Higher Education \\
\hline 1. & They have strong, involved boards & They have strong, involved trustees \\
\hline 2. & $\begin{array}{l}\text { They continually expose their top } \\
\text { management to the board }\end{array}$ & $\begin{array}{l}\text { They continually expose their vice-president/vice chancellor } \\
\text { to the trustees }\end{array}$ \\
\hline 3. & $\begin{array}{l}\text { They encourage next generation CEO's to } \\
\text { gain exposure to outside board service, to } \\
\text { the media, and to the investment } \\
\text { community }\end{array}$ & $\begin{array}{l}\text { They encourage next generation president/vice chancellor to } \\
\text { gain exposure to outside community, to the media, and to the } \\
\text { alumni membership }\end{array}$ \\
\hline 4. & $\begin{array}{l}\text { They form executive committees or } \\
\text { operating committees to facilitate the } \\
\text { development of several executives who are } \\
\text { aware of the challenges, business plans and } \\
\text { strategies across the entire organization }\end{array}$ & $\begin{array}{l}\text { They form executive committees or operating committees to } \\
\text { facilitate the development of several administrators who are } \\
\text { aware of the challenges, business plans and strategies across } \\
\text { the entire institution }\end{array}$ \\
\hline 5. & $\begin{array}{l}\text { They pay their directors increasingly } \\
\text { instock and require the directors to make a } \\
\text { personal investment in the company }\end{array}$ & $\begin{array}{l}\text { They require the trustees to make a personal commitment to } \\
\text { the institution }\end{array}$ \\
\hline 6. & $\begin{array}{l}\text { They periodically calibrate likely internal } \\
\text { candidates for CEO against comparable } \\
\text { outside leaders }\end{array}$ & $\begin{array}{l}\text { They periodically calibrate likely internal candidates for } \\
\text { president/vice chancellor against comparable outside leaders }\end{array}$ \\
\hline
\end{tabular}

